УДК 159.9

doi: $10.15330 /$ ps.9.1.16-21

Рафал Абрамцьов

Державний педагогічний університет імені Національної комісії

з питань освіти у Кракові (Польща)

abramciow@gmail.com

\title{
ФЕНОМЕН НЕРЕФЛЕКСИВНОЇ (ЕМОЦІЙНОЇ) СВІДОМОСТІ САРТРА
}

У статті аргументується засаднича теза екзистенційно-феноменологічної концепиї Сартра про первинну нерозчленовану єдність людини та ї̈ свідомості і світу, до якої вона, як суб'єкт, залучена завдяки притаманній ій інтенціональності - спрямованості на зовнішні предмети. Нерефлексивна свідомість функціонує на спонтанному чуттєвому рівні пізнання і не скеровується свідомим себе «Я». Цим самим нерефлексивна (емоційна) свідомість людини репрезентує екзистенційний модус буття у світі як творчого переживання $i$ нетривіального бачення об'єктів пізнання в щуоразу нових зв'язках і відношеннях. При изьому емоція постає специффічним способом пізнання суб'єктом «об'єктивної» дійсності, щзо відрізняє ї̈ від деяких інших психічних прочесів своєю непозичійністю, тобто стихійною безпосередністю й органічним зв 'язком із оточенням.

Застосування феноменологічного методу в психології особистості, щуо базується на представленому уявленні, дасть змогу реалізувати иүілісний аксіологічний підхід до вивчення психічних явищ, який враховує актуальний життєвий контекст буття людини, ї̈ потреби, мотиви, інтереси, переконання $і$ цінності.

Так трактований феномен нерефлексивної (емоційної) свідомості Сартра протистоїть як редукиіонізму позитивістської (біхевіоральної) психологї, так $і$ психоаналізу Фройда, але водночас може бути стимулом для розгортання досліджень у ияарині сучасної когнітивної психології, зокрема психології емоційного інтелекту.

Ключові слова: свідомість, нерефлексивна свідомість, рефлексія, психологія емоцій, феноменологічна концепџія емоцій Сартра, цілісний аксіологічний підхід.

Постановка проблеми. Розглядаючи психологію емоцій 3 історичної перспективи, можна зауважити, що існує багато способів опису відношення «емоція - свідомість». Зазвичай структуральні описи вказують на такі індивідуальні відмінності, як риси (Strelau [11]), пізнавальні - схеми, переконання і атрибуції (Pervin [6], Trzebińska [13]), мотиваційні, як-от особисті прагнення і проекти (Emmons [3]) чи функціональні, пов'язані з еволюційними поясненнями (Buss [1]).

Мета статті полягає у філософсько-психологічному обгрунтуванні феноменологічного методу для з'ясування нерефлексивної, емоційно забарвленої природи людської свідомості. Автор вважає, що відношення «емоція - свідомість» найкраще описано у феноменологічній моделі J. P. Sartre'a 3 огляду на ii голістичність і мінімальну редукованість. Ніхто 3 феноменологів, крім власне J. P. Sartre'а, не розумів це відношення так широко і неспотворено.

\section{Феноменологічна концепція нерефлексивної свідомості}

У своїх феноменологічних дослідженнях J. P. Sartre поставив чіткі цілі і завдання перед психологією феноменологічною. Визнаючи експериментальні дослідження емоцій за недостатні для розуміння природи емоцій та посилаючись на дедалі зростаючу недовіру щодо певних даних як дослідного матеріалу і підстав для наук емпіричних, він пропонує визначати поведінку людини не в категоріях чи термінах реакцій (фізіологічних чи психологічних), але в категоріях знаків (того, що означає), які відсилають до ситуації в світі, до відносин і зв 'язків зі світом зовнішнім.

Та сартрівська пропозиція визначила засадничо новий напрям пізнання природи емоцій та мала визначальне значення для конструювання власної теорії емоцій. За J. P. Sartre’oм (1960) [8] дослідження природи емоцій не може бути обмежено класичним підходом експериментальних наук з притаманним їм методом індукції.

У позитивістській психології, стверджує Sartre (1943) [7], кожне психічне явище трактується як певний факт, конкретне буття, відтак психічні явища позбавляються значущих рис, якостей. Деякі психологи, наприклад, біхевіористи найбільше зацікавлені в тому, щоб ізолювати і не допустити до свідомості ті факти. Останні повинні досліджуватися «такими, 
якими є». Якщо появився чинник (стимул), то неминуче мусить з'явитися наслідок (реакція). У разі дослідження природи емоцій вся множина стимулів, які викликають емоції та емоційні реакції, повинна визначатися у причинно-наслідковому зв'язку, і ця взаємодія мусить бути цілковито позбавлена вибірково-значущого ставлення суб'єкта до оточення, оскільки при цьому можна було б втратити певну «об'єктивність» дослідження.

Отже, J. P. Sartre (1943) [7] вважає, що всі теорії психології детерміністичної (всілякі форми репрезентаціонізму й асоціаціонізму, біхевіоризму), позбавляють свідомість притаманної ій активності і спонтанності, зводячи іiі до певного типу вузько спричиненого механізму, упускаючи те, що в самій структурі емоції $є$ найістотнішим, тобто ії інтенціональний характер, який відсилає до того, що є значущим, а отже в результаті відсилання до цілісності стосунків людини і світу.

Для Sartre'a (1960) [8] емоція нерозривно пов'язана зі структурою свідомості і не може бути досліджена незалежно від неї. Кажучи дещо метафорично, вона не тільки «є» у світі, але водночас у ньому «діє».

У психології розрізняють різні види свідомості. Насамперед ідеться про найелементарнішу iї форму - чуттєву, або притомності людини, наступною простою формою свідомості є свідомість перцептивна, яка часто визначається як чуттєва сприйнятливість, нарешті найвищим видом свідомості $€$ самосвідомість як певна метакогнітивна здатність власних психічних процесів [12, с. 253].

Згідно з феноменологічно-пізнавальною парадигмою J. P. Sartre (1960) [8] розрізняють свідомість як власне явище (conscience reflet), і свідомість як щось, що можна класифікувати на широко зрозуміле переживання (conscience reflectant) або на свідомість нерефлексивну (як свідомість-у-світі, що діє спонтанно) і свідомість рефлексивну (спрямовану на себе). Відповідні ій структури «відповідають» фізіологічними реакціями або станами свідомості, коли хочуть зазначити свою присутність у світі.

Таке феноменологічне розширення розуміння свідомості людини чи «розшарування» $\dddot{1}$ структури є неодмінною умовою для аналізу самого феномену емоції. Відкриття Sartre'ом існування нерефлексивної свідомості має велике значення для пізнання природи емоції. Адже емоція є не тільки фактом, відокремленим від свідомості у сенсі чогось первинно буттєвого, того, що потрібно лиш ідентифікувати й описати. Також не є лише психічним станом або тільки «вмістом» свідомості, оскільки емоція як психічний стан зазвичай відноситься до тимчасової реакції на специфічний вид зумовлень. Вона не $\epsilon$ також якась психічна властивість, тому що психічна властивість стосується певної схильності до реагування у певний особливий спосіб на певний вид умов. Натомість у випадку емоції видається, що вона перевищує власну схему реагування. Насамкінець вона не є тільки фізіологічним досвідом, ані тільки поведінкою суб'єкта, але широко зрозумілим феноменом, який становить результат творчих актів свідомості, є власне сповненим значення актом свідомості.

Як уже відзначалося вище, істотним мотивом пошуків Sartre'a було звертання уваги на те, що певна помилка до появи феноменологічних теорій полягала у сліпій вірі в силу фактів. Нагромадження даних, додавання «старих» фактів до «ново»знайдених неуникно приводить до ігнорування того, що є суттєвим, до віддання переваги тому, що є випадковим, «коштом» того, що істотне.

Без сумніву, такі дослідження є надзвичайно потужні, але треба усвідомлювати, що на їх підставі можливий тільки один тип психологічного пояснення, котрий задовольняється характерною для наук експериментальних каузальністю. Опертя психологічних пояснень тільки на причинно-наслідковий зв'язок неминуче мусить приводити до нехтування інтенціонально-цільових аспектів структури емоції, які у феноменологічній моделі свідомості відіграють провідну роль. Зведення досліджень лише до емоційних процесів, відірваних від свідомості, втрачає з поля зору різноманіття інтенціональних спрямувань свідомості, які надають сенсу самому переживанню емоції. Sartre'y зрозуміло, що нагромадження щораз 
нових фактів, навіть їх великої кількості, не вкаже на eidos явища емоції. Радше навпаки структура чогось уможливлює погляд на саму природу фактів.

Сучасна методологія науки немає жодних сумнівів у тому, наскільки сильно значення може змінити сприймання даного предмету пізнання, а також на поведінку. Крім того, більшість сучасних підручників загальної психології визнають засадничий факт, що сприймання чи спостереження завжди певним чином зумовлене нашим попереднім досвідом, очікуваннями передбаченнями.

Аргумент Sartre'a на користь вибору феноменологічного методу в дослідженні емоцій полягає в тому, що повинен бути первинний рівень свідомості як свідомості нерефлексивної, спрямованої на світ, і це становить підставу різних досліджень, описів і аналізу феномену емоції на цьому рівні. Саме завдяки існуванню нерефлексивної свідомості емоція може виникнути. I тому, як явище психічне, непозиційне, емоція відноситься до людини як до джерела єдності свідомості-емоції та суб'єкта, який емоцію викликав.

Аналіз суб'єктного виміру емоції як безумовного джерела пізнання вказує на те, що, наприклад, усвідомлення страху вторинне і сильно залежить від того, що діється безпосередньо і спонтанно у світлі свідомості нерефлексивної: «Боячись, ще не маємо усвідомлення страху» [8, с. 38]. Суть нерефлексивного виміру свідомості окреслена в такій цитаті: «Однак страх первинно не є свідомістю того, що ми боїмося, не більше, ніж споглядання цієї ось книжки $\epsilon$ свідомістю того, що бачимо книжку. Емоційна свідомість насамперед є нерефлексивною і в цьому сенсі може бути свідомістю самої себе тільки у спосіб непозиційний. Емоційна свідомість є передовсім свідомістю світу. Необов'язково мати повне уявлення про теорію свідомості, аби зрозуміти це (...). Очевидно, що людина, котра боїться, боїться чогось. Навіть коли йдеться про один із тих невизначених страхів, які переживаємо в темряві тощо, то згодом відчуваємо страх перед певними аспектами ночі, світу. Не сумніваючись, всі психологи зауважили, що сприймання викликало емоції, певну сигнальну репрезентацію тощо. Та видається, що на наступному етапі емоція відділяється від об’єкта, щоб зануритися в саму себе. Не потрібно довго думати, щоб довести протилежне, що емоція кожної миті повертається до об'єкта і живиться ним (...). Одним словом, суб'єкт зворушений і об'єкт, що зворушує, перебувають у нерозривному синтезі. Емоція $є$ певним способом розуміння світу» [8, с. 39].

J. P. Sartre (1963) [10] закидає класичним психологічним теоріям хибне уявлення про емоції як про сталі, пасивні і статичні речі чи як стани свідомості. На його думку, щоб пізнати те, чим $\epsilon$ емоція, необхідно аналізувати людину-в-світі-емоції, аналізувати структуру свідомості, а не тільки емоції як зовнішнього факту щодо самої свідомості.

Інтенціональність як фундаментальна властивість структури свідомості на нерефлексивному рівні повертає свідомість до цілісності стосунків людини і світу. На думку Sartre'a, існує строга відповідність між емоцією і способом іiі розуміння. Опис емоції повинен починатися з опису людини, а не від попереднього опису іï емоційності як такої, що конституює буття людини.

Отже, одним із найважливіших «відкриттів» теорії емоцій J. P. Sartre’a $\epsilon \quad$ свідомість нерефлексивна. Як нерефлексивна, вона функціонує незалежно від рефлексії та без допомоги останньої. Вона є свідомістю-в-світі, як визначив ï сам Sartre (1960) - «активна», «спрямована» на світ. Це «відкриття» має фундаментальне значення для його феноменологічної теорії емоцій. «Я» свідоме, психічне «Я», відома картезіанська рефлексивна думка, яка ділила цілісність психічного життя людини, або «Я» трансцендентальне Гуссерля, на думку Sartre'a, не спрацьовують на нерефлексивному рівні свідомості. Емоційній свідомості не потрібно використовувати у своїй діяльності свідоме «Я». Емоційна свідомість начебто «вкинута в світ» і організує себе сама у свій власний спосіб. У разі переживання емоції, але тільки емоції, підкреслює Sartre, - моє свідоме «Я» може бути присутнє.

Таким чином емоція, не будучи тільки станом свідомості, що надається до опису й аналізу, не будучи також ідентичною з поведінкою і фізіологічними симптомами організму, на думку 
Sartre'a (1960) [8], подібно до сприймання, мислення, уяви є специфічним способом розуміння світу. Тим самим не тільки «Я» свідоме може організувати життя людини, це може також робити емоційна свідомість, яка не відає про своє «Я». Отже, Sartre показує, що діяльна спонтанна нерефлексивна свідомість являє собою певний екзистенційний шар світу. Щоб діяти, не потрібно бути свідомим себе самого як того, хто діє.

Для того, щоб краще зрозуміти суть нерефлексивної свідомості, додам розлогу цитату Sartre'a: «Ми занадто схильні вірити, що діяльність $є$ постійним переходом від нерефлексивності до рефлексивності, від світу до нас самих. В той самий спосіб будемо розуміти проблему (брак рефлексії - усвідомлення світу), далі - самих себе як таких, що мають проблему, котра потребує розв'язання (рефлексія); почавши з цієї рефлексії, будемо розуміти дію, яку мусимо зробити (рефлексія), а згодом, повертаючись назад, підемо до світу, щоб виконати діяльність (нерефлексивну), вже маючи на увазі тільки предмет діяльності (...) Отож бачимо, що можемо розмірковувати про нашу діяльність. Але діяльність у світі найчастіше виконується без пропуску суб'єктом нерефлексивного плану. Наприклад, пишучи це, я не маю усвідомлення писання. Якщо хтось скаже, що це прояв несвідомої рухової навички, яку виконує моя рука, коли виводить літери, то це було б абсурдом. Я може і маю навичку писання, але не навичку писання таких слів у такому порядку (...). В дійсності акт писання не $\epsilon$ в жодному разі несвідомим; це актуальна структура моєї свідомості. Лише він не свідомий самого себе» [8, с. 40].

Окрім того, мусимо в цьому контексті ще згадати про суть емоційної поведінки. Нерефлексивна свідомість виражається в емоційній поведінці і творить світ переживання, представлений у специфічному якісному модусі. Sartre (1960) [8] бачить виразні межі можливості впливу емоційної свідомості на зовнішній світ. Визнаючи за емоціями здатність трансцендування поза суб'єктивність та їхню спрямованість на зовнішні предмети щодо самого акту свідомості, він водночас обмежує діапазон емоційної поведінки людини. Феноменологічний опис конкретного прикладу, який наводить сам Sartre, дозволить нам краще зрозуміти суть проблеми, яка тут розглядається: «Пошук дула, захованого в головоломці «Де рушниця?» полягає в перцептивному поводженні з гілкою дерева по-новому, телефонних стовпів, візерунку так, щоб знайти дуло рушниці, для чого треба виконати такі рухи очами, які виконували $б$ із цим зображенням. Але ми не схоплюємо цих рухів як таких. Попри це трансцендувальна інтенція цілісності, яка керує цими рухами, спрямовується на дерева і стовпи, зрозумілі як можливі рушниці, аж до моменту, поки раптова перцепція не кристалізується і не 3'явиться рушниця. Так само, як шляхом зміни інтенції, змінюється поведінка, коли ми розуміємо новий предмет, або і старий предмет, але по-новому. При цьому не мусимо з самого початку займати позицію на рефлексивному плані. Легенда зображення слугує безпосередньою мотивацією. Ми шукаємо рушницю, не виходячи з нерефлексивного плану. Це означає, що потенційна рушниця появиться невиразно локазованою в зображенні. Потрібно зрозуміти зміну інтенції та поведінки, яка характеризує емоції таким чином. Неможливість знаходження розв'язання проблеми, зрозумілої об'єктивно як властивість світу, слугує мотивацією до нової нерефлексивної свідомості, яка розуміє світ щоразу по-іншому, в новому аспекті» [8, с. 43].

В інтерпретації нерефлексивної свідомості Sartre’а можна спробувати шукати аналогії 3 відкриттями психоаналізу Z. Freuda. Адже головним відкриття психоаналізу було відкриття несвідомого як такого, що керує нашим психічним життям і надає йому свого значення. Однак відмінність між емоційною свідомісю Sartre’a і несвідомим Z. Freuda є принципова.

Емоційна свідомість $є$ нерефлексивною, але це не означає, що вона є несвідомою. За Sartre'ом (1960) [8], вона свідома себе у спосіб неетичний, тобто не керується свідомим «Я», позаяк виражає первинний зв'язок зі світом, тому є свідомим переживанням, сповненим предметного змісту.

Тим часом, за Фройдом, несвідоме як фундаментальний пласт психіки оперує ії внутрішнім планом, який $\epsilon$ ірраціональним й алогічним. В несвідомому точаться численні 
конфлікти, які разом з іншими несвідомими змістами та процесами важко або неможливо усвідомити, але які водночас сильно впливають на людське функціонування і досвід (Freud, 1992) [4].

Висновки. Завдяки відкриттям феноменологічної психології, особливо теорії свідомості й емоцій J. P. Sartre'a, сучасна когнітивна психологія не протиставляє процеси свідомі та несвідомі. Несвідоме не є частиною психіки, сповненою конфліктними прагненнями чи потягами, але властивістю пізнавальних процесів, яка, з огляду на обмежені засоби свідомої уваги, не може перебувати в іiі центрі. (Eagle, 1987; Kihlstrom, 1987). Когнітивна наука не приписує несвідомому такого великого значення, якого йому приписував Freud. Несвідомі змісти і процеси можуть бути дуже швидко усвідомлені і контрольовані (Eagle, 1987 [2]; Pervin, $2002[6])$.

Однак незалежно від відмінностей феноменологічної нерефлексивно-емоційної свідомості від психоаналітичної концепції несвідомого можна стверджувати, що як одна, так і друга призвела до звернення пильної уваги на психічні процеси, що відбуваються поза свідомим «Я» як представником психічного життя, що стосовно досліджуваного предмету видається найважливішим.

1. Buss, D. M. (2001). Psychologia ewolucyjna. Jak wyttumaczyć spoleczne zachowania czlowieka? Najnowsze koncepcje. Gdańsk: Gdańskie Wydawnictwo psychologiczne.

2. Eagle, M. N. (1987). The psychoanalytic and the cognitive uncounsciousness. W: Stern R. (red.). Theories of uncounsciousness and theories of self. Hillsdale, NJ: Erlbaum.

3. Emmons, R. A. (1986). Personal strivings: An approach to personality and subjective well-being. Journal of Personality and Social psychology, 52, 1058-1068.

4. Freud, Z. (1992). O psychoanalizie. Poznań: Oficyna Wydawnicza Bookservice.

5. Husserl, E. (1965). Kryzys nauk europejskich i fenoemnologia transcendentalna. Warszawa: Państwowy Instytut Wydawniczy PIW.

6. Pervin, L. A. (2000). Psychologia osobowości. Gdańsk: Gdańskie Wydawnictwo Psychologiczne.

7. Sartre, J. P. (1943). L'etre et le neant. Paris: Edition Gallimard.

8. Sartre, J. P. (1960). Esquisse d'une theorie des emotions. Paris: Editeurs des sciences et des arts, Hermann.

9. Sartre, J. P. (1968). Les Situations. Paris: Edition Gallimard.

10. Sartre, J.P. (1963). La transcendence de l'ego. Paris: Editeurs des sciences et des arts. Hermann.

11. Strelau, J. (2000). Psychologia. Podręcznik akademicki. Psychologia ogólna. Gdańsk: Gdańskie Wydawnictwo Psychologiczne

12. Tomaszewski, T. T. (1966). Aktywność człowieka. W: M. Maruszewski, J. Reykowski, T. Tomaszewski Psychologia jako nauka o człowieku. Warszawa, KiW.

13. Trzebińska, E. (1998). Dwa wizerunki własnej osoby: studia nad sposobami rozumienia siebie. Warszawa: Wydawnictwo Instytutu Psychologii PAN.

\section{Rafal Abramciov \\ SARTRE'S PHENOMENON OF NON-REFLEXIVE (EMOTIONAL) CONSCIOUSNESS}

The article argues the fundamental thesis of Sartre's existential and phenomenological concept of initial undivided unity of a person with its consciousness and the world which it belongs to as the subject due to its characteristic intentionality - focus on external objects. Non-reflexive consciousness functions on the spontaneous sensual level of cognition and is not directed by the conscious of the self "I". Thus, the non-reflexive (emotional) human consciousness represents the existential modus of being in the world as a creative experience and non-trivial vision of objects of cognition in every time new connections and relations. Herewith, emotion acts as a specific way of experiencing "objective" reality by the subject which differs it from some other mental processes by its non-positionality, that is, by accidental spontaneity and organic bond with the environment.

The application of the phenomenological method in the personality psychology based on the presented ideas makes it possible to realize the integral axiological approach to the study of mental phenomena considering human actual vital context of being, its needs, motives, interests, beliefs and values.

The interpreted in such a way Sartre's phenomenon of non-reflexive (emotional) consciousness opposes to both reductionism of positivist (behavioral) psychology and Freud's psychoanalysis but at the same time it could be an incentive for the deployment of study in the field of modern cognitive psychology, psychology of emotional intelligence in particular.

Keywords: consciousness, non-reflexive consciousness, reflection, psychology of emotions, Sartre's phenomenological concept of emotions, integral axiological approach. 